\title{
Preparation and characterization of silk fibroin as a biomaterial with potential for drug delivery
}

\author{
Hao Zhang ${ }^{1 \dagger}$, Ling-ling $\mathrm{Li}^{2 \dagger}$, Fang-yin Dai ${ }^{3}$, Hao-hao Zhang ${ }^{1}$, Bing Ni ${ }^{1}$, Wei Zhou ${ }^{1}$, Xia Yang ${ }^{1 *}$ and Yu-zhang $\mathrm{Wu}^{1 *}$
}

\begin{abstract}
Background: Degummed silk fibroin from Bombyx mori (silkworm) has potential carrier capabilities for drug delivery in humans; however, the processing methods have yet to be comparatively analyzed to determine the differential effects on the silk protein properties, including crystalline structure and activity.

Methods: In this study, we treated degummed silk with four kinds of calcium-alcohol solutions, and performed secondary structure measurements and enzyme activity test to distinguish the differences between the regenerated fibroins and degummed silk fibroin.

Results: Gel electrophoresis analysis revealed that $\mathrm{Ca}\left(\mathrm{NO}_{3}\right)_{2}$-methanol, $\mathrm{Ca}\left(\mathrm{NO}_{3}\right)_{2}$-ethanol, or $\mathrm{CaCl}_{2}$-methanol treatments produced more lower molecular weights of silk fibroin than $\mathrm{CaCl}_{2}$-ethanol. X-ray diffraction and Fourier-transform infrared spectroscopy showed that $\mathrm{CaCl}_{2}$-ethanol produced a crystalline structure with more silk I (a-form, type II $\beta$-turn), while the other treatments produced more silk II ( $\beta$-form, anti-parallel $\beta$-pleated sheet). Solid-State ${ }^{13} \mathrm{C}$ cross polarization and magic angle spinning-nuclear magnetic resonance measurements suggested that regenerated fibroins from $\mathrm{CaCl}_{2}$-ethanol were nearly identical to degummed silk fibroin, while the other treatments produced fibroins with significantly different chemical shifts. Finally, enzyme activity test indicated that silk fibroins from $\mathrm{CaCl}_{2}$-ethanol had higher activity when linked to a known chemotherapeutic drug, L-asparaginase, than the fibroins from other treatments.
\end{abstract}

Conclusions: Collectively, these results suggest that the $\mathrm{CaCl}_{2}$-ethanol processing method produces silk fibroin with biomaterial properties that are appropriate for drug delivery.

Keywords: Silk fibroin, Calcium-alcohol solutions, Crystalline structure, Drug delivery, Biomaterial

\section{Background}

Silk fibers produced by silkworms are widely used in our daily life. While they have occupied an important niche in the textile industry for thousands of years, their potential as biomaterials has been recognized and developed only over the past decade [1]. Being non-toxic, non-immunogenic, and biocompatible with a broad range of animal species has allowed for the adherent properties of silk fibroin and silk-like proteins to be exploited for biomedical purposes. To date, silk fibroins have mainly been applied to wound healing, successfully performing as man-made blood-vessels [2], surgical sutures [3], and repair materials [4]. New processing

\footnotetext{
* Correspondence: oceanyangx@gmail.com; wuyuzhang20006@sohu.com

${ }^{\dagger}$ Equal contributors

'Institute of Immunology Third Military Medical University, Chongqing 400038, Peoples Republic of China

Full list of author information is available at the end of the article
}

strategies for silk fibers and proteins have expanded the biomedical utility of these molecules. For example, the gel spun silk-based matrix derived from silk fibroin was successfully applied for bladder augmentation in a murine model [5]. More recently, scientists determined that the cocoons from Bombyx mori harbor antioxidant and hypolipidemic properties and that the crude silk extracts have bioactivity against hypercholesterolemia and atherosclerosis [6].

Recently, the regenerated silk fibroin has been proved as an attractive candidate of a carrier for drug or therapeutic proteins delivery and is the focus of much ongoing research. Attachment of bioactive molecules or therapeutic proteins to silk fibroin has many benefits to enhance the properties of bioactive molecules in solution for delivery both in vitro and in vivo, including the therapeutic efficacy in the body, thermal stability, storage stability, and lengthens the circulatory half-life and

\section{Biomed Central}


decreases immunogenicity and antigenicity [3]. For instance, bioconjugations of insulin, glucose oxidase, Lasparaginase (L-ASNase), lipase and phenylalanine ammonia-lyase with the regenerated silk fibroin greatly improved their biological stability, reduced the immunogenicity and toxicity of the drug [7-11]. Moreover, The SELP (silk-elastinlike protein polymer)-controlled gene delivery approach could potentially improve activity of adenoviral-mediated gene therapy of head and neck cancer and limit viral spread to normal organs at the same time [12].

It has been known that the properties of silk-matrix are controlled by a combination of the chemistry and the spinning process, which directly affect the activity and stability of the enzymes attached. Spinning conditions, such as temperature, drawing rate, time, and specific type of silkworm, can modulate biomaterial features. In addition, chemistry, such as ion concentration, type of ion, and solution $\mathrm{pH}$, can also affect the mechanical properties of silk fibroins [1]. In previous studies, degummed fibroin has generally been treated with aqueous solutions of hexafluoro-isopropanol (HFIP) [13], methanol [8], $\mathrm{CaCl}_{2}$-ethanol [7,9], or $\mathrm{Ca}\left(\mathrm{NO}_{3}\right)_{2}$ methanol [14]. Lu et al. has reported glucose oxidase attached to the regenerated silk fibroin film without treated with methanol remain more activity but lower stability than that treated with methanol [8]. After crosslinking L-ASNase with regenerated silk fibroin prepared with concentrated $\mathrm{CaCl}_{2}$ mixture solution with ethanol and water (1:2:8, mol), the immunogenicity and toxicity of the drug significantly reduced, and its circulatory half-life lengthened in vitro [9].

However, these studies have used only one treatment per experiment and, up to now, the systematic comparative analysis to distinguish the difference of those treatments has not yet been reported, thus we do not know which one is the best choice for future potential application. Here, we describe our systematic comparative analysis of silk fibroins prepared with four of the commonly used preparative solutions, $\mathrm{Ca}\left(\mathrm{NO}_{3}\right)_{2}$-methanol, $\mathrm{Ca}\left(\mathrm{NO}_{3}\right)_{2^{-}}$ ethanol, $\mathrm{CaCl}_{2}$-methanol, and $\mathrm{CaCl}_{2}$-ethanol. The results could help to reveal the mechanisms of properties of silkderived matrix under different treating conditions and provide evidence to choose right solution to prepare silk fibroins for potential drug delivery applications.

\section{Materials and methods}

\section{Materials}

L-asparaginase (L-ASNase) from E. coli (10,000 IU) was purchased from Changzhou Qianhong Bio-Pherma Co., Ltd. (Jiangsu Province, China). L-asparagines' (anhydrous) was purchased from Sangon Biotech (Shanghai) Co., Ltd. (Shanghai, China). Trichloroactic acid (TCA) was purchased from Sinopharm Chemical Reagent Co.,
Ltd. (Beijing, China). Methanol, ethanol, calcium nitrate tetrahydrate $\left(\mathrm{Ca}\left(\mathrm{NO}_{3}\right)_{2} \cdot 4 \mathrm{H}_{2} \mathrm{O}\right)$, calcium chloride $\left(\mathrm{CaCl}_{2}\right)$, and $\mathrm{HgI}_{2}$, all analytical reagent grade, were purchased from Chengdu Kelong Chemical Reagent Factory (Sichuan Province, China).

\section{Preparation of degummed silk fibroin}

Cocoons from $B$. mori were degummed by incubating in a mixture of sodium dodecyl sulfate (SDS; $0.25 \%, \mathrm{w} / \mathrm{v}$ ) and sodium carbonate $(0.25 \%, \mathrm{w} / \mathrm{v})$ at $98^{\circ} \mathrm{C}$ for $30 \mathrm{~min}$. The samples were then cooled to room temperature, rinsed three times with deionized water, and dried at $65^{\circ} \mathrm{C}$ overnight. The ratio of cocoons and solution was 1:100 (w/v). The degummed silk fibroins were isolated, along with another silk protein, sericin.

\section{Calcium-alcohol solvents treatment of silk fibers}

The isolated fibroin fibers were separately dissolved in concentrated $\mathrm{CaCl}_{2}$ solution mixed with ethanol or methanol and water (1:2:8 mol), and separately dissolved in concentrated $\mathrm{Ca}\left(\mathrm{NO}_{3}\right)_{2} \cdot 4 \mathrm{H}_{2} \mathrm{O}$ solution mixed with ethanol or methanol $(1: 2 \mathrm{~mol})$ at $65^{\circ} \mathrm{C}$ in a water bath for $1 \mathrm{~h}$. The ratio of the silk fibers and solution was 1:20 $(\mathrm{m} / \mathrm{v})$. The aqueous solution of silk fibroin was obtained by dialyzing against flowing water. After that, the resulting dialyzed solutions were lyophilized. The dry silk powder (fibroins treated with $\mathrm{CaCl}_{2}$-ethanol solution) or pieces (from the other three solutions) were stored at $4^{\circ} \mathrm{C}$ until use.

\section{SEM}

The silk fibroins were vacuum-coated with a $20 \mathrm{~nm}$ layer of gold. The surface morphology of each silk fibroin was observed with a scanning electron microscope (S-3400N SEM; Hitachi, Japan) and photographed at a voltage of $15 \mathrm{kV}$ and room temperature.

\section{SDS-polyacrylamide gel electrophoresis (PAGE)}

The silk fibroins separately treated with $\mathrm{Ca}\left(\mathrm{NO}_{3}\right)_{2}$ methanol, $\mathrm{Ca}\left(\mathrm{NO}_{3}\right)_{2}$-ethanol, $\mathrm{CaCl}_{2}$-methanol, and $\mathrm{CaCl}_{2}$-ethanol solution were analyzed by SDS-PAGE to determine the corresponding molecular weights of the protein. Samples were resolved on 12\% acrylamide gel and $4 \%$ condensing gel, and protein bands were visualized by staining with $0.25 \%$ Coomassie Brilliant Blue R-250 (Sigma-Aldrich, St. Louis, MO, USA).

\section{FTIR spectroscopy}

The infrared spectra of each fibroin produced with $\mathrm{Ca}$ $\left(\mathrm{NO}_{3}\right)_{2}$-methanol, $\mathrm{Ca}\left(\mathrm{NO}_{3}\right)_{2}$-ethanol, $\mathrm{CaCl}_{2}$-methanol, and $\mathrm{CaCl}_{2}$-ethanol solution, and degummed fibroins (as control), were measured on a FTIR spectrometer using $\mathrm{KBr}$ pellets (Tensor 27 FTIR; Bruker, Ettlingen, Germany). Spectra, with a resolution of $4 \mathrm{~cm}^{-1}$, were 
recorded and subtracted from the sample readings. All samples were measured in reflection mode; for this, the silk fibroin powder treated with $\mathrm{CaCl}_{2}$-ethanol solution had been transformed into tablet form. The results are presented as the average of 64 repeated $4000 \sim 400 \mathrm{~cm}^{-1}$ scans.

\section{WAXD}

The crystalline structure of the silk fibroins produced with $\mathrm{Ca}\left(\mathrm{NO}_{3}\right)_{2}$-methanol, $\mathrm{Ca}\left(\mathrm{NO}_{3}\right)_{2}$-ethanol, $\mathrm{CaCl}_{2}$ methanol, and $\mathrm{CaCl}_{2}$-ethanol solution, and of degummed fibroins, were determined by WAXD using a Siemens type F X-ray diffractometer (Siemens, Munich, Germany) with $\mathrm{Ni}$-filtered $\mathrm{Cu} \mathrm{K} \alpha$ radiation. The voltage and current of the X-ray source were $30 \mathrm{KV}$ and $20 \mathrm{~mA}$, respectively. The wavelength, $\lambda$, was $0.15406 \mathrm{~nm}$. The samples were mounted on aluminum frames and scanned from $5^{\circ}$ to $40^{\circ}(2 \theta)$ at a speed of $2^{\circ} / \mathrm{min}$. The Dspacing was calculated by the following equation: $\mathrm{D}=\lambda$ / $(2 \times \sin (\theta))$, i.e. $\mathrm{D}=0.0752 /(\sin \theta) \mathrm{nm}$. For example, if the scanning angel was $2 \theta=20^{\circ}$, then $\mathrm{D}=0.0752 /\left(\sin 10^{\circ}\right)$ $\mathrm{nm}$, and the D-space was $0.43 \mathrm{~nm}$.

\section{Solid-state ${ }^{13} \mathrm{C} C P / M A S-N M R$ spectra measurement}

Solid state ${ }^{13} \mathrm{C}$ CP/MAS-NMR has been successfully used to analyze the secondary structure of proteins [15], and was similarly applied in our study. The ${ }^{13} \mathrm{C} \mathrm{CP} /$ MAS-NMR spectra were recorded on a Bruker AVANCE III $400 \mathrm{WB}$ spectrometer equipped with a $4 \mathrm{~mm}$ standard bore $\mathrm{CP} / \mathrm{MAS}$ probe head, whose $\mathrm{X}$ channel was tuned to $100.62 \mathrm{MHz}$ for ${ }^{13} \mathrm{C}$ and the other channel was tuned to $400.18 \mathrm{MHz}$ for broad band $1 \mathrm{H}$ decoupling. A magnetic field of $9.39 \mathrm{~T}$ at $297 \mathrm{~K}$ was used. The dried and finely powdered samples were packed in a $\mathrm{ZrO}_{2}$ rotor that was sealed with an Kel-F cap and spun at $12 \mathrm{kHz}$ rate. The experiments were conducted at a contact time of $2 \mathrm{~ms}$. A total of 3000 scans were recorded with $6 \mathrm{~s}$ recycle delay for each sample. All ${ }^{13} \mathrm{C} \mathrm{CP} / \mathrm{MAS}$ chemical shifts were referenced to the resonances of the adamantane $(\mathrm{C} 10 \mathrm{H} 16)$ standard $(\delta \mathrm{CH} 2=38.5)$.

\section{Enzyme cross-linking and activity test}

L-ASNase immobilization was performed according to the method previously described by Zhang et al. [16] with minor modifications. An aliquot $(50 \mathrm{mg})$ of each fibroin produced with $\mathrm{Ca}\left(\mathrm{NO}_{3}\right)_{2}$-methanol, $\mathrm{Ca}\left(\mathrm{NO}_{3}\right)_{2}$ ethanol, $\mathrm{CaCl}_{2}$-methanol, and $\mathrm{CaCl}_{2}$-ethanol solution, and degummed fibroins (as control), were placed into plastic centrifuge tubes and mixed with $2 \mathrm{~mL}$ L-ASNase in phosphate buffered saline (PBS) solution $(2 \mathrm{mg} / \mathrm{mL}$ ) and $1 \mathrm{~mL}$ L-asparagine PBS solution ( $5 \mathrm{mg} / \mathrm{L})$. The Lasparagine acted as the enzyme activity center protector. After gentle shaking, glutaraldehyde (0.05\%) and PBS $(\mathrm{pH}$ 7.4) were added to bring the final volume to $5 \mathrm{~mL}$, and the solutions were incubated at $4^{\circ} \mathrm{C}$ overnight to facilitate the cross-linking reaction. The next day, the reaction was stopped by adding $100 \mathrm{mg}$ glycine to each tube. The fibroin and L-ASNase bioconjugates were then washed with Tris- $\mathrm{HCl}$ buffer $(\mathrm{pH}$ 8.6) and purified by centrifugation in a J2-MI refrigerated centrifuge (Beckman-Coulter, Brea, CA, USA) at $10000 \mathrm{rpm}$ for $10 \mathrm{~min}$ at $4^{\circ} \mathrm{C}$; this purification process was repeated three times with intervening Tris- $\mathrm{HCl}$ washes. After the final spin, the pellets were each resuspended in $1 \mathrm{~mL}$ Tris $-\mathrm{HCl}$ and incubated in a water bath at $37^{\circ} \mathrm{C}$ for $10 \mathrm{~min}$. Two milliliters of $5 \mathrm{mg} / \mathrm{mL}$ L-asparagine in Tris- $\mathrm{HCl}$ was added to each tube, and incubation continued at $37^{\circ} \mathrm{C}$ for another $10 \mathrm{~min}$. The enzymatic reaction was terminated by adding $100 \mathrm{mg}$ TCA to each reaction. The tubes were centrifuged at $3000 \mathrm{rpm}$ for $5 \mathrm{~min}$, and 0.5 $\mathrm{mL}$ of the supernatant from each was transferred to fresh centrifuge tubes containing $1 \mathrm{~mL}$ Nessler's reagent. After the reaction processed at room temperature for a given time, $50 \mu \mathrm{L}$ of each mixture and $150 \mu \mathrm{L}$ of Tris$\mathrm{HCl}$ buffer were transferred in triplicate to 96 well microplates. The same experiment was repeated three times. The activities of the enzymes attached to the fibroins were calculated by determining the change in optical density at $450 \mathrm{~nm}$ as measured on a microplate reader (Paradigm; Beckman-Coulter). Data are presented as mean $\pm \mathrm{SD}$ and evaluated using the Student's $t$-test (SPSS 13.0, SPSS Inc.). $P<0.05$ was considered to be statistically significant. The mobilization and activity detection of glucose oxidase were performed by referring to the published literature [8].

\section{Results and discussion}

Morphology of silk fibroins

The silk fibroins treated with $\mathrm{Ca}\left(\mathrm{NO}_{3}\right)_{2} \cdot 4 \mathrm{H}_{2} \mathrm{O}$-methanol, $\mathrm{Ca}\left(\mathrm{NO}_{3}\right)_{2} \cdot 4 \mathrm{H}_{2} \mathrm{O}$-ethanol, $\mathrm{CaCl}_{2}$-methanol- $\mathrm{H}_{2} \mathrm{O}$, and $\mathrm{CaCl}_{2}$ ethanol solution were separately dissolved. After lyophilized, the surface morphology of degummed silk fibroins and regenerated silk fibroins was observed with SEM (Figure 1). The size and shape of the degummed silk fibroins were normal, with diameters of 6-8 $\mu \mathrm{m}$ (Figure 1A). In contrast, the regenerated silk fibroins were spherical or irregular shapes. This shape may have resulted from the merger of smaller micelles that occurred in the aqueous solutions of $\mathrm{Ca}\left(\mathrm{NO}_{3}\right)_{2} \cdot 4 \mathrm{H}_{2} \mathrm{O}$-methanol (Figure $1 \mathrm{~B}$ ), $\mathrm{Ca}\left(\mathrm{NO}_{3}\right)_{2} \cdot 4 \mathrm{H}_{2} \mathrm{O}$-ethanol (Figure $1 \mathrm{C}$ ), and $\mathrm{CaCl}_{2}$-methanol- $\mathrm{H}_{2} \mathrm{O}$ (Figure $1 \mathrm{D}$ ), and $\mathrm{CaCl}_{2}$-ethanol (Figure 1E).

\section{Molecular weight ranges of silk fibroins}

The silkworm's cocoon is composed of two kinds of silk protein, the silk sericin, which makes up the membrane, and the silk fibroin, which makes up the inner portion. The silk sericin is a glue-like mixture of glycoproteins 

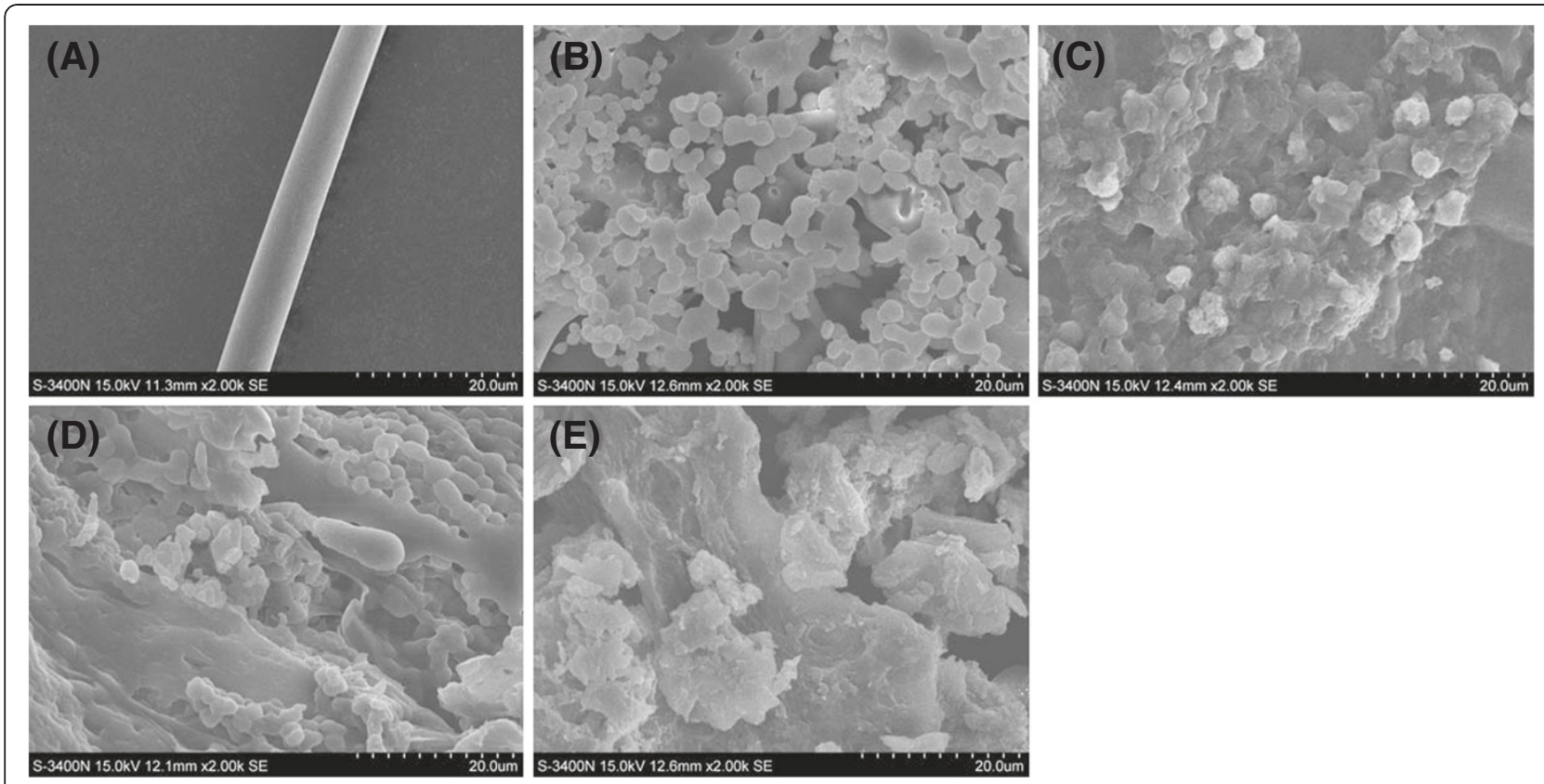

Figure $1 \mathrm{SEM}$ photographs of $\boldsymbol{B}$. mori silk fibroin prepared with various solutions. (A) Degummed silk fibroin. (B) Silk fibroin prepared from $\mathrm{Ca}\left(\mathrm{NO}_{3}\right)_{2} \cdot 4 \mathrm{H}_{2} \mathrm{O}$-methanol solution. (C) Silk fibroin prepared from $\mathrm{Ca}\left(\mathrm{NO}_{3}\right)_{2} \cdot 4 \mathrm{H}_{2} \mathrm{O}$-ethanol solution. (D) Silk fibroin prepared from $\mathrm{CaCl}$-methanol$\mathrm{H}_{2} \mathrm{O}$ solution. (E) Silk fibroin prepared from $\mathrm{CaCl}_{2}$-ethanol- $\mathrm{H}_{2} \mathrm{O}$ solution.

with varying molecular mass, and is removed by the degumming and rinsing steps. The silk fibroin protein of $B$. mori is rich in alanine, glycine and serine residues [17], and is $\sim 400 \mathrm{kDa}$, with $300 \mathrm{kDa}$ making up a heavy chain (H-chain), $26 \mathrm{kDa}$ making up a light chain (Lchain), L-chain and $\mathrm{H}$-chain linked by disulfide bond(s) and about $30 \mathrm{kDa}$ making up a P25 glycoprotein that associates with the $\mathrm{H}-\mathrm{L}$ complex primarily by hydrophobic interactions [18].

The silk fibroins produced with $\mathrm{Ca}\left(\mathrm{NO}_{3}\right)_{2}$-methanol, $\mathrm{Ca}\left(\mathrm{NO}_{3}\right)_{2}$-ethanol, $\mathrm{CaCl}_{2}$-methanol, and $\mathrm{CaCl}_{2}$-ethanol solutions were dissolved, and the molecular weights were measured by SDS-PAGE. As shown in Figure 2, the regenerated silk fibroins treated with $\mathrm{Ca}\left(\mathrm{NO}_{3}\right)_{2}$-methanol had a molecular weight from about $95 \mathrm{KDa}$ to over $170 \mathrm{kDa}$, but $\mathrm{Ca}\left(\mathrm{NO}_{3}\right)_{2}$-ethanol from about $100 \mathrm{KDa}$ to over $170 \mathrm{kDa}$. The $\mathrm{CaCl}_{2}$-methanol solution fibroins ranged from about 140 to over $170 \mathrm{kDa}$, while the $\mathrm{CaCl}_{2}$-ethanol fibroins ranged from about 100 to nearly $300 \mathrm{kDa}$. Two low molecular weight bands, $\sim 17$ and $\sim 26$ $\mathrm{kDa}$, were obviously present in these regenerated silk fibroins, but the silk fibroins produced with $\mathrm{CaCl}_{2}$-ethanol showed relatively faint low molecular weight bands at these positions. In addition, the degummed silk fibroins are poorly soluble, except in the chemistry solution and organic solvents, we could not observe obvious bands in the gel.

This phenomenon suggested that some of the disulfide linkages and hydrophobic bonds, between silk fibroin

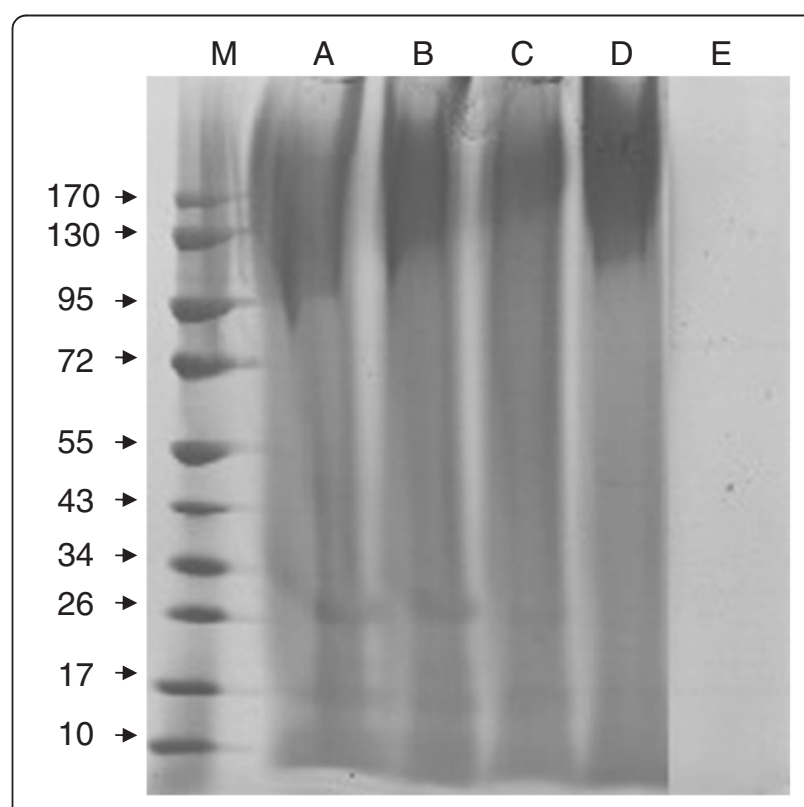

Figure 2 SDS-PAGE analysis of B. mori silk fibroins prepared with various solutions. Silk fibroins were prepared from four different calcium-alcohol solutions (as described below) then dissolved in hot water. The range of molecular weight of the proteins produced by each solution was determined by SDS-PAGE with $12 \%$ acrylamide gel and $4 \%$ condensing gel, which was stained with $0.25 \%$ Coomassie Brilliant Blue R-250. Lanes: $\mathrm{M}$, marker. (A) silk fibroin prepared from $\mathrm{Ca}\left(\mathrm{NO}_{3}\right)_{2} \cdot 4 \mathrm{H}_{2} \mathrm{O}-$ methanol solution. (B) silk fibroin prepared from $\mathrm{Ca}\left(\mathrm{NO}_{3}\right)_{2} \cdot 4 \mathrm{H}_{2} \mathrm{O}$-ethanol solution. (C) silk fibroin prepared from $\mathrm{CaCl}_{2}$-methanol- $\mathrm{H}_{2} \mathrm{O}$ solution. (D) silk fibroin prepared from $\mathrm{CaCl}_{2}$-ethanol- $\mathrm{H}_{2} \mathrm{O}$ solution. (E) Degummed silk fibroin. 
molecules may have been destroyed by $\mathrm{Ca}\left(\mathrm{NO}_{3}\right)_{2}$ methanol, $\mathrm{Ca}\left(\mathrm{NO}_{3}\right)_{2}$-ethanol, or $\mathrm{CaCl}_{2}$-methanol treatments. The solvent of $\mathrm{CaCl}_{2}$-ethanol appeared to be sufficiently gentle to produce silk fibroins with less obvious damage to the secondary bonds. Thus, the $\mathrm{CaCl}_{2}$-ethanol solution may be superior to the other solutions in its ability to protect the integrity of the fibroin secondary structure. The regenerated silk protein treated with these calcium-alcohol solvents were water-soluble, this results consistent with published reports that the silk proteins prepared from $\mathrm{Ca}\left(\mathrm{NO}_{3}\right)_{2}$-methanol were water-soluble, indicating that the regenerating coagulants affected the crystallinity and conformation of the fibroin [14].

\section{Fourier-transform infrared spectroscopic analysis of the silk fibroins' crystalline structure}

Due to the presence of amide groups in silk protein, the characteristic vibration bands around $1620 \mathrm{~cm}^{-1}$ were assigned to the absorption peak of the peptide backbone of amide I ( $\mathrm{C}=\mathrm{O}$ stretching), bands around $1513 \mathrm{~cm}^{-1}$ to amide II (N-H bending), the bands around 1230 and $1444 \mathrm{~cm}^{-1}$ to amide III (C-N stretching) [15], and $694 \mathrm{~cm}^{-1}$ to amide IV $[19,20]$. All these characteristic absorbance peaks indicate the existence of a hydrogen-bonded $\mathrm{NH}$ group [21]. The molecular conformation of $B$. mori silk fibroin is characterized by $\beta$-sheet absorption peaks around 1630, 1530 and $1240 \mathrm{~cm}^{-1}$, random coil conformation absorption peaks at 1650 or 1645,1550 and $1230 \mathrm{~cm}^{-1}$, and an $\alpha$-helix absorption peak around $1655 \mathrm{~cm}^{-1}$ $[15,22]$. Tang and colleagues had previously reported that the intensity of peaks around $3300 \mathrm{~cm}^{-1}$ (data not shown here) fluctuate in response to hydrogen bonds [23].

In Figure 3, the $\beta$-sheet conformation was indicated by shifts of absorption peaks as follows: 1625-1630 $\mathrm{cm}^{-1}$ (amide I), $1520-1530 \mathrm{~cm}^{-1}$ (amide II), and 1265-1270 $\mathrm{cm}^{-1}$ (amide III). FTIR spectra of the regenerated silk fibroins showed intense absorption peaks around 1620 $\mathrm{cm}^{-1}, 1514 \mathrm{~cm}^{-1}$, and $1230 \mathrm{~cm}^{-1}$, which are the characteristic absorption peaks of $\beta$-sheet. The detected crystalline structure of $\mathrm{CaCl}_{2}$-ethanol silk fibroin showed more silk I ( $\alpha$-form, type II $\beta$-turn), while that of the other three fibroins showed more silk II ( $\beta$-form, antiparallel $\beta$-pleated sheet).

\section{Wide-angle X-ray diffraction analysis of the silk fibroins crystalline structure}

The toughness of silk fibers is dependent on their $\beta$-sheet composition. In spider and cocoon silk, the $\beta$-sheet consists of a poly-alanine or a GAGAGAGAAS sequence, arranged in an anti-parallel or parallel conformation. A previous study by Lu et al. demonstrated that the corresponding $D$-spacings of silk I ( $\alpha$-form, type II $\beta$-turn)

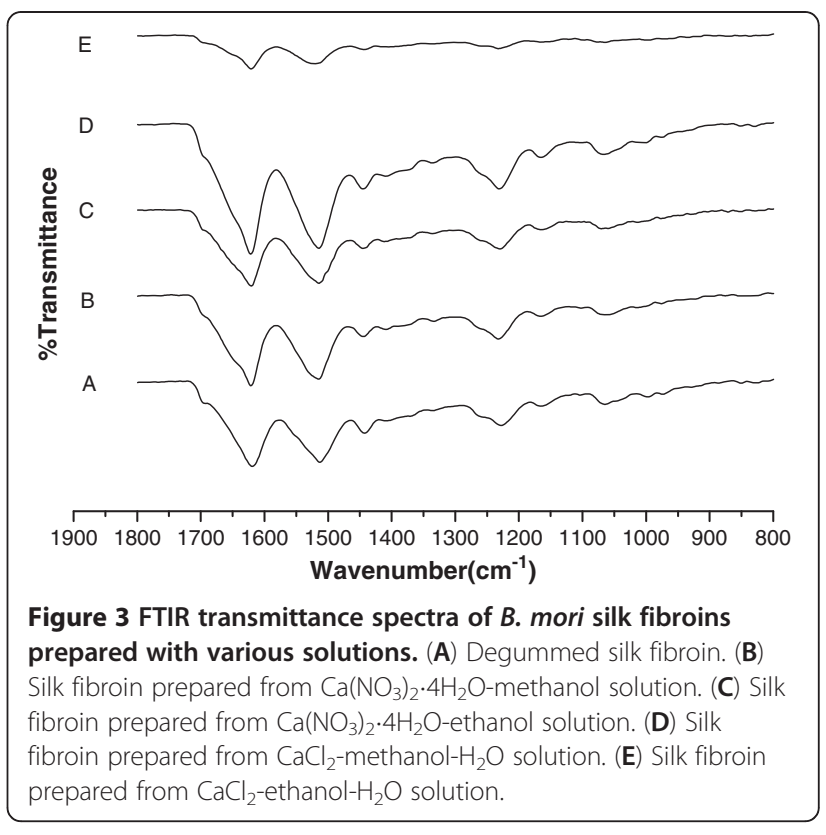

were $0.74 \mathrm{~nm}, 0.56 \mathrm{~nm}, 0.44 \mathrm{~nm}, 0.41 \mathrm{~nm}, 0.36 \mathrm{~nm}, 0.32$ $\mathrm{nm}$, and $0.28 \mathrm{~nm}$, and of silk II ( $\beta$-form, anti parallel $\beta$ pleated sheet) were $0.98 \mathrm{~nm}, 0.48 \mathrm{~nm}$, and $0.43 \mathrm{~nm}$ [24].

Figure 4 shows the WAXD data of the regenerated silk fibroins produced in our study with $\mathrm{Ca}\left(\mathrm{NO}_{3}\right)_{2}$-methanol, $\mathrm{Ca}\left(\mathrm{NO}_{3}\right)_{2}$-ethanol, $\mathrm{CaCl}_{2}$-methanol, and $\mathrm{CaCl}_{2}$-ethanol solutions. The degummed fibroin and fibroins produced with $\mathrm{Ca}\left(\mathrm{NO}_{3}\right)_{2}$-methanol, $\mathrm{Ca}\left(\mathrm{NO}_{3}\right)_{2}$-ethanol, and $\mathrm{CaCl}_{2}$ methanol showed similar $2 \theta$ diffraction peaks, which corresponded to silk II crystalline spacing of $0.47 \mathrm{~nm}$ $\left(2 \theta=18.4^{\circ}\right)$, and silk I crystalline spacing of $0.39 \mathrm{~nm}$ $\left(2 \theta=22.4^{\circ}\right)$. In contrast, fibroin treated with $\mathrm{CaCl}_{2}$ -

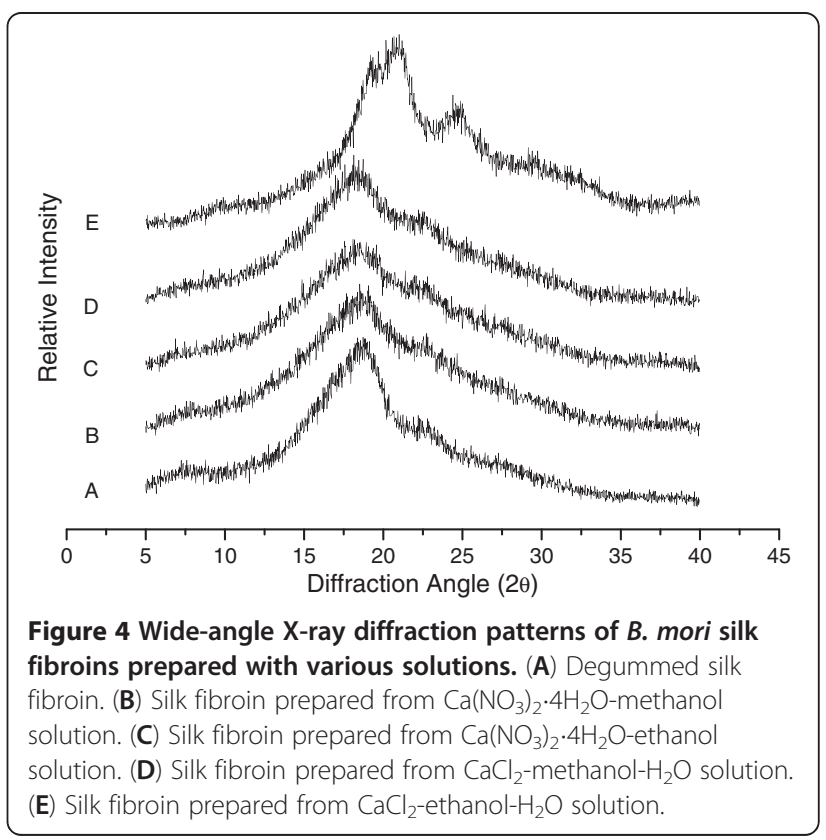


ethanol showed four obvious diffraction peaks at $2 \theta$, namely $19.4^{\circ}, 20.3^{\circ}, 24.6^{\circ}$, and $29.3^{\circ}$, which corresponded to silk I crystalline spacing of $0.44 \mathrm{~nm}, 0.41 \mathrm{~nm}, 0.35$ $\mathrm{nm}$, and $0.30 \mathrm{~nm}$, respectively. No typical diffraction peaks of silk II were found for this regenerated silk fibroin. The mean peak at $2 \theta=18.4^{\circ}$ for fibroins treated with $\mathrm{Ca}\left(\mathrm{NO}_{3}\right)_{2}$-methanol, $\mathrm{Ca}\left(\mathrm{NO}_{3}\right)_{2}$-ethanol, or $\mathrm{CaCl}_{2}$ methanol was not as sharp as that for degummed fibroin. This finding indicated that these solutions decreased the crystallization ability of fibroin, and the sharp peak observed at $2 \theta=20.3^{\circ}$ of $\mathrm{CaCl}_{2}$-ethanol fibroins indicated an increased crystallization ability of fibroin.

Furthermore, the fibroins produced with $\mathrm{CaCl}_{2}$-ethanol were composed of more silk I ( $\alpha$-form, type II $\beta$-turn) than the other three regenerated fibroins and the degummed fibroin, which had more silk II ( $\beta$-form, antiparallel $\beta$-pleated sheet). As reported previously, the standard orientation methods, such as rolling and drawing, are able to transform the metastable silk I into silk II [25]. Therefore, it is possible that the $\mathrm{CaCl}_{2}$-ethanol solution is superior to the other solutions in its ability to protect the integrity of the fibroin, maintaining more silk I.

\section{Solid-state ${ }^{13} \mathrm{C}$ CP/MAS-NMR analysis of the conformational and inter-molecular arragement of silk fibroins}

As shown in Figure 5, the peaks on the dotted line marked Ala $C_{\beta}$ II (16.8 ppm) correspond to the representative peaks of random coil or distorted $\beta$-turn, where the torsion angles of a backbone chain are distributed largely around the averaged angles of silk II structure [26]. The other two peaks that were observed, at 20.2 and $22.6 \mathrm{ppm}$, correspond to anti-parallel $\beta$-sheets [27]. However, the presence of peaks of Ala $C_{\beta}$ at $15.2 \mathrm{ppm}$ and Ala $C_{\alpha}$ at $52.4 \mathrm{ppm}$ suggested that the residues strongly favor an ordered structure, most likely a helical structure [28]. According to previous studies, the silk protein consists of many repeated motif sequences, such as AGSGAG [29], AGYGAG, AGVGYGAG and GAAS [30]; since glycine and alanine can readily form peptide bonds, this is a likely event in the regenerated silk fibroins.

The peaks of alanine and serine carbons that were observed in our study samples suggest that all of them contain random coils or distorted $\beta$-turns (16.8 ppm peak). An increased amount of these peaks was found in the fibroins produced with $\mathrm{Ca}\left(\mathrm{NO}_{3}\right)_{2}$-methanol, $\mathrm{Ca}$ $\left(\mathrm{NO}_{3}\right)_{2}$-ethanol, and $\mathrm{CaCl}_{2}$-methanol, as compared with degummed silk fibroins and silk fibroins treated with $\mathrm{CaCl}_{2}$-ethanol (Figure 5).

The peak position of the $C_{\alpha}$ and $C_{\beta}$ carbons from alanine and serine residues indicate clearly that these samples had a $\beta$-sheet structure. The silk fibroins produced

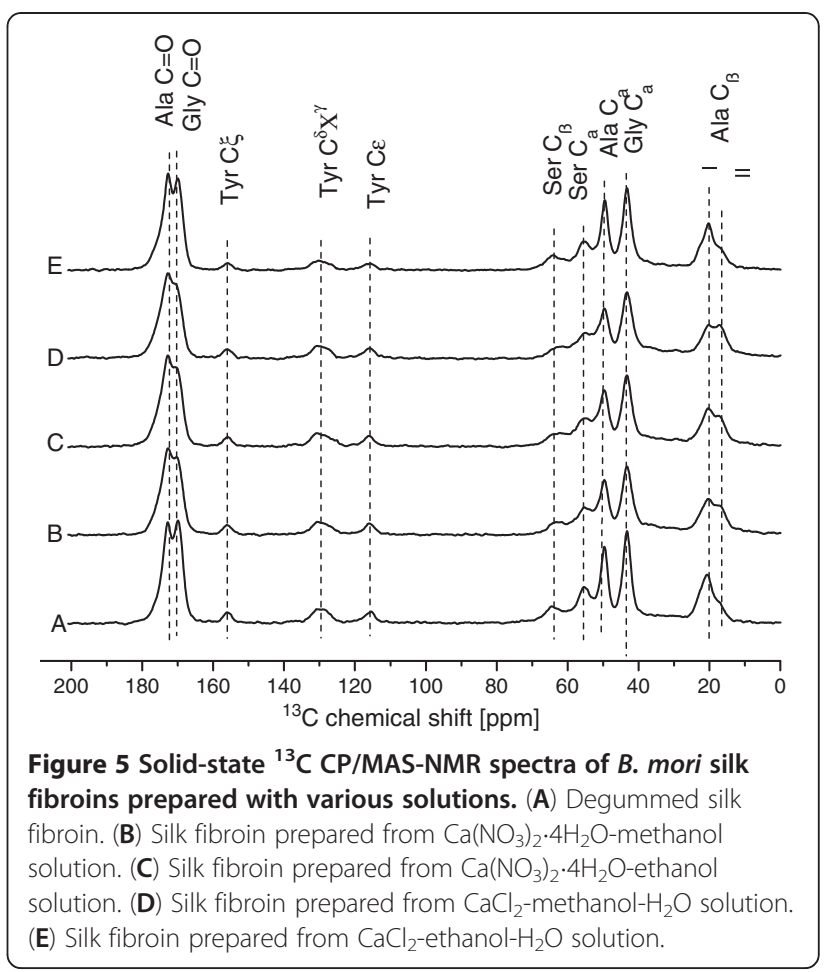

with $\mathrm{Ca}\left(\mathrm{NO}_{3}\right)_{2}$-methanol, $\mathrm{Ca}\left(\mathrm{NO}_{3}\right)_{2}$-ethanol, and $\mathrm{CaCl}_{2}$ methanol solutions showed increased peaks for alanine $\mathrm{C}_{\beta}$ and decreased peaks for glycine with $\mathrm{C}=\mathrm{O}$ (169.1 ppm peak) interactions between them. Furthermore, the peaks of silk fibroin produced with $\mathrm{CaCl}_{2}$-ethanol were nearly identical to those for the degummed silk fibroin sample. This finding may be related to the different levels of chemical shift that were produced by the $\mathrm{Ca}$ $\left(\mathrm{NO}_{3}\right)_{2}$-methanol, $\mathrm{Ca}\left(\mathrm{NO}_{3}\right)_{2}$-ethanol, and $\mathrm{CaCl}_{2}$-methanol solutions. Regardless, the regenerated fibroin produced with $\mathrm{CaCl}_{2}$-ethanol solution appeared to be the best method to protect the conformational and intermolecular arrangement of the silk fibroin chains of degummed fibroin.

\section{Enzymatic activity of L-ASNase when conjugated with silk fibroins}

L-asparaginase is a well-established chemotherapeutic agent in routine use to treat acute lymphoblastic leukemia. However, treatment withdrawal due to side effects, some life-threatening and immunological reactions is not uncommon [31]. In addition, circulation half-life is short, necessitating longer and larger doses of the drug.

In this study, we tested whether any of the four silk fibroins produced by the different solutions had more beneficial effects on a bioconjugated enzyme that is relevant for human therapy. The L-ASNase enzyme was chosen for these in vitro experiments, along with its substrate L-asparagine. Since L-ASNase hydrolysis of L- 
asparagine produces $\mathrm{NH}_{3}$, Nessler's reagent, which turns yellow in the presence of $\mathrm{NH}_{3}$, was chosen to measure L-ASNase activity. According to the results, the activity of L-ASNase attached to the regenerated fibroins produced with $\mathrm{CaCl}_{2}$-ethanol solution was higher than the other fibroins (Figure 6A). The highest activity of glucose oxidase-linked to the four silk fibroins was observed in $\mathrm{CaCl}_{2}$-ethanol group too, very similar to that observed for L-ASNase (Figure 6B). Therefore, the $\mathrm{CaCl}_{2}$-ethanol solution appear to be the most appropriate methods by which to prepare regenerated silk fibroins for use as drug delivery carriers, at least for these two particular enzymes. However, the immunogenicity and biocompatibility properties of these regenerated silk fibroins produced with $\mathrm{CaCl}_{2}$-ethanol have yet to be determined and require further investigation in an animal model before clinical application.

Silk is a unique protein biopolymer, with a block copolymer structure dominated by large hydrophobic domains and small hydrophilic spacers. This primary structure, upon folding into assembled silk structures, leads to organized crystalline domains ( $\beta$-sheets) and less

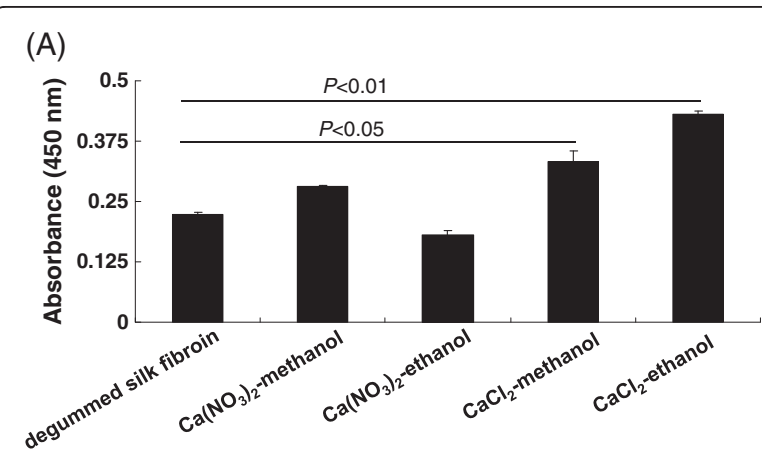

(B)

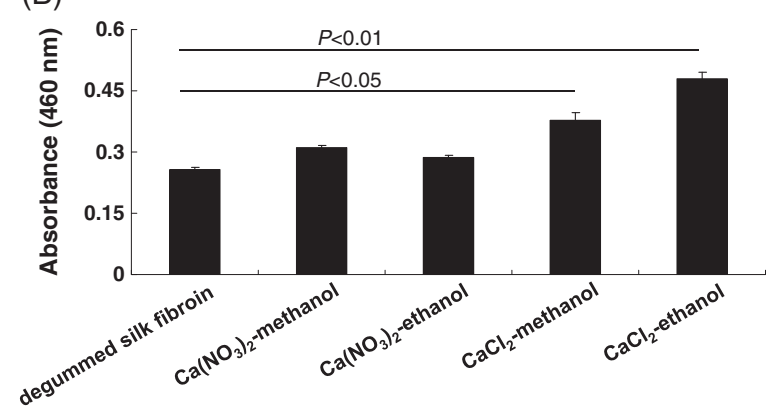

Figure 6 Enzyme activity tests for silk fibroins prepared with various solutions. L-ASNase $(\mathbf{A})$ and glucose oxidase $(\mathbf{B})$ were separately immobilized to degummed silk fibroin or regenerated fibroins prepared from four different calcium-alcohol solutions. The activities of these enzymes attached to the fibroins were calculated as a change in optical density at 450 or $460 \mathrm{~nm}$ measured on a microplate reader, accordingly. Results are presented as mean \pm SD ( $n=3$ assays of triplicate samples). $P<0.05$ was considered to be statistically significant. organized more flexible domains (more hydrated). This assembly leads to localized nanoscale pockets where other proteins may be entrapped with limited but sufficient hydration [8]. The silk biomaterial offers some important features that suggest utility as a stabilization matrix. In addition, methanol and ethanol treatment of silk fibroin resulted in a gradual transition from silk I to silk II $[32,33]$. The analyses also indicated that formation of aggregated strands among extended sericin chains induced by ethanol treatment is the key to generating molecular orientation [34]. Other research showed that the chimeric protein which formed by a clone encoding consensus repeats from the major protein in the spider dragline silk of Nephila clavipes fused to the carboxyl terminal domain of dentin matrix protein 1 (CDMP1) was incubated with $\mathrm{CaCl}_{2}$, the secondary structure shifted from random coil to $\alpha$-helix and $\beta$-sheet, due to the interactions between the CDMP1 domain and $\mathrm{Ca}^{2+}$ [35]. The results confirmed that concentrated neutral salts such as $\mathrm{Ca}^{2+}$, or organic solvents including methanol and ethanol can affected the crystallinity and conformation of the fibroin. However, the molecular mechanisms for these effects have to be clarified in the future.

The degradation rate of a matrix is an important parameter for a biomaterial designed to be used for tissue engineering applications. The properties of silk-matrix also directly affect the enzymatic degradation of the enzymes attached. Random coil and $\alpha$-helical structures formed of the biospun fibroin accelerate the process of degradation in both PBS and enzyme solutions in comparison with $\beta$-sheets [36]. Zhang et al. reported that cross-linking L-ASNase with regenerated silk fibroin treated with $\mathrm{CaCl}_{2}$-ethanol solution significantly increased heat and storage stability and resistance to trypsin digestion, and its longer half-life (63 h) than that of control L-ASNase (33 h) [9]. These observations also suggested that the silk-based matrix prepared with $\mathrm{CaCl}_{2}$-ethanol solution formed more crystalline domains $(\beta$-sheets) potentially help to decrease the degradation rate.

It's concluded that regenerated silk fibroin can be used as an immobilization matrix for enzymes or therapeutic proteins. The properties of the regenerated silk-matrix directly effect the activity and stability of the enzymes attached. In the present research, Fourier-transform infrared spectroscopy and X-ray diffraction showed that the regenerated silk-matrix treated with $\mathrm{CaCl}_{2}$-ethanol has a crystalline structure with more silk I ( $\alpha$-form, type II $\beta$-turn), while the silk-matrixes treated with other solutions have more silk II $(\beta$-form, anti-parallel $\beta$ pleated sheet). Solid-State ${ }^{13} \mathrm{C} C \mathrm{CP} / \mathrm{MAS}-\mathrm{NMR}$ analysis also suggested that the silk-matrix regenerated from $\mathrm{CaCl}_{2}$-ethanol were nearly identical to degummed silk fibroin, while the others show significantly different 
chemical shifts. These results suggested that the silkbased matrix prepared with $\mathrm{CaCl}_{2}$-ethanol solution formed more crystalline domains ( $\beta$-sheets) than others, which potentially helps to enhance the stability and improve activity of drug or therapeutic proteins. Furthermore, the properties of the regenerated silk-matrix can satisfy the needs of modern carrier materials, ruling out the use of most synthetic polymer materials, thus the carrier materials of silk fibroin treated with $\mathrm{CaCl}_{2}$-ethanol could be widely applicable.

In addition, a range of medical needs such as silk sutures, drug delivery systems, and fiber-based tissue products that exploit the mechanical properties of silks can be envisioned for ligament, bone, and other tissue repairs may become more and more popular in the next few years [1]. These materials based on silk fiber can lead to multifunctional material platforms that integrate with living systems for medical materials, industrial material and a host of other applications.

\section{Conclusions}

Preparation of B. mori degummed silk fibroin by $\mathrm{CaCl}_{2}-$ ethanol preserved the best original protein structure and produced a better affinity to the enzyme drug L-ASNase than the $\mathrm{Ca}\left(\mathrm{NO}_{3}\right)_{2}$-methanol, $\mathrm{Ca}\left(\mathrm{NO}_{3}\right)_{2}$-ethanol and $\mathrm{CaCl}_{2}$-methanol treatments. The $\mathrm{CaCl}_{2}$-ethanol solution may represent the most appropriate method by which to prepare silk fibroins for use as biomaterials, especially as carriers for drug delivery.

\section{Competing interests}

The authors declare that they have no competing interests.

\section{Authors' contributions}

Hao Zhang and Ling-ling Li mainly performed research; in addition, Hao Zhang analyzed data and wrote the paper. Xia Yang designed research, analyzed data and wrote the paper. Fang-yin Dai, Hao-hao Zhang and Wei Zhou helped to prepare the materials and performed research. Bing $\mathrm{Ni}$ revised the manuscript. Yu-zhang Wu participated in the design of the study and provided administrative support. All authors have contributed and approved the final manuscript.

\section{Acknowledgements}

We would like to thank Dr. Jennifer C. van Velkinburgh (van Velkinburgh Initiative for Collaboratory BioMedical Research, USA) for helpful discussions and for polishing this manuscript.

\section{Author details \\ 'Institute of Immunology Third Military Medical University, Chongqing 400038, Peoples Republic of China. 'Biochemistry engineering department, Chongqing Industry \& Trade Polytechnic, Chongqing 408000, Peoples Republic of China. ${ }^{3}$ State Key Laboratory of Silkworm Genome Biology, Southwest University, Chongqing 400715, Peoples Republic of China.}

Received: 29 January 2012 Accepted: 21 May 2012

Published: 7 June 2012

\section{References}

1. Omenetto FG, Kaplan DL: New opportunities for an ancient material. Science 2010, 329:528-531.
2. Lovett M, Eng G, Kluge JA, Cannizzaro C, Vunjak-Novakovic G, Kaplan DL: Tubular silk scaffolds for small diameter vascular grafts. Organogenesis 2010, 6:217-224.

3. Altman GH, Diaz F, Jakuba C, Calabro T, Horan RL, Chen J, Lu H, Richmond J, Kaplan DL: Silk-based biomaterials. Biomaterials 2003, 24:401-416.

4. Leal-Egana A, Scheibel T: Silk-based materials for biomedical applications. Biotechnol Appl Biochem 2010, 55:155-167.

5. Mauney JR, Cannon GM, Lovett ML, Gong EM, Di Vizio D, Gomez P 3rd, Kaplan DL, Adam RM, Estrada CR Jr: Evaluation of gel spun silk-based biomaterials in a murine model of bladder augmentation. Biomaterials 2011, 32:808-818.

6. Ali MM, Arumugam SB: Effect of crude extract of Bombyx mori coccoons in hyperlipidemia and atherosclerosis. J Ayurveda Integr Med 2011, 2:72-78.

7. Zhang $Y Q$, Ma $Y$, Xia $Y Y$, Shen WD, Mao JP, Zha XM, Shirai K, Kiguchi K: Synthesis of silk fibroin-insulin bioconjugates and their characterization and activities in vivo. J Biomed Mater Res B Appl Biomater 2006, 79:275-283.

8. Lu S, Wang X, Lu Q, Hu X, Uppal N, Omenetto FG, Kaplan DL: Stabilization of enzymes in silk films. Biomacromolecules 2009, 10:1032-1042.

9. Zhang YQ, Zhou WL, Shen WD, Chen YH, Zha XM, Shirai K, Kiguchi K: Synthesis, characterization and immunogenicity of silk fibroin-Lasparaginase bioconjugates. J Biotechno/ 2005, 120:315-326.

10. Chatterjee S, Barbora L, Cameotra SS, Mahanta P, Goswami P: Silk-fiber immobilized lipase-catalyzed hydrolysis of emulsified sunflower oil. Appl Biochem Biotechnol 2009, 157:593-600.

11. Inoue $S$, Matsunaga $Y$, Iwane $H$, Sotomura M, Nose T: Entrapment of phenylalanine ammonia-lyase in silk fibroin for protection from proteolytic attack. Biochem Biophys Res Commun 1986, 141:165-170.

12. Greish K, Frandsen J, Scharff S, Gustafson J, Cappello J, Li D, O'Malley BW Jr, Ghandehari H: Silk-elastinlike protein polymers improve the efficacy of adenovirus thymidine kinase enzyme prodrug therapy of head and neck tumors. J Gene Med 2010, 12:572-579.

13. Zhu ZH, Ohgo K, Asakura T: Preparation and characterization of regenerated Bombyx mori silk fibroin fiber with high strength. Express Polymer Letters 2008, 2:885-889.

14. Ha SW, Park YH, Hudson SM: Dissolution of Bombyx mori silk fibroin in the calcium nitrate tetrahydrate-methanol system and aspects of wet spinning of fibroin solution. Biomacromolecules 2003, 4:488-496.

15. Ha SW, Tonelli AE, Hudson SM: Structural studies of Bombyx mori silk fibroin during regeneration from solutions and wet fiber spinning. Biomacromolecules 2005, 6:1722-1731

16. Zhang $Y Q$, Tao ML, Shen WD, Zhou YZ, Ding Y, Ma Y, Zhou WL: Immobilization of L-asparaginase on the microparticles of the natural silk sericin protein and its characters. Biomaterials 2004, 25:3751-3759.

17. Lotz B, Colonna Cesari F: The chemical structure and the crystalline structures of Bombyx mori silk fibroin. Biochimie 1979, 61:205-214.

18. Tanaka $K$, Inoue S, Mizuno S: Hydrophobic interaction of P25, containing Asn-linked oligosaccharide chains, with the $\mathrm{H}-\mathrm{L}$ complex of silk fibroin produced by Bombyx mori. Insect Biochem Mol Biol 1999, 29:269-276.

19. Chuan Xin Liang KH: Improvements of the physical properties of fibroin membranes with sodium alginate. J Appl Polym Sci 1992, 45:1937-1943.

20. Anshu Bagga Mathur AT, Thomas Rathke, Sam Hudson: The dissolution and characterization of Bombyx mori silk fibroin in calcium nitrate-methanol solution and the regeneration of films. Biopolymers 1997, 42:61-74.

21. Freddi G, Pessina G, Tsukada M: Swelling and dissolution of silk fibroin (Bombyx mori) in N-methyl morpholine N-oxide. Int J Biol Macromol 1999, 24:251-263.

22. Meinel L, Hofmann S, Karageorgiou V, Kirker-Head C, McCool J, Gronowicz G, Zichner L, Langer R, Vunjak-Novakovic G, Kaplan DL: The inflammatory responses to silk films in vitro and in vivo. Biomaterials 2005, 26:147-155

23. Tang Y, Cao C, Ma X, Chen C, Zhu H: Study on the preparation of collagen-modified silk fibroin films and their properties. Biomed Mater 2006, 1:242-246.

24. Lu Q, Hu X, Wang X, Kluge JA, Lu S, Cebe P, Kaplan DL: Water-insoluble silk films with silk I structure. Acta Biomater 2010, 6:1380-1387.

25. He SJ, Valluzzi R, Gido SP: Silk I structure in Bombyx mori silk foams. Int J Biol Macromol 1999, 24:187-195.

26. Zhu Z, Kikuchi Y, Kojima K, Tamura T, Kuwabara N, Nakamura T, Asakura T: Mechanical properties of regenerated Bombyx mori silk fibers and 
recombinant silk fibers produced by transgenic silkworms. J Biomater Sci Polym Ed 2010, 21:395-411.

27. Yao J, Asakura T: Synthesis and structural characterization of silk-like materials incorporated with an elastic motif. J Biochem 2003, 133:147-154.

28. Zhao C, Yao J, Masuda H, Kishore R, Asakura T: Structural characterization and artificial fiber formation of Bombyx mori silk fibroin in hexafluoroiso-propanol solvent system. Biopolymers 2003, 69:253-259.

29. Fraser RD, MacRae TP, Stewart FH: Poly-l-alanylglycyl---alanylglycyl-Iserylglycine: a model for the crystalline regions of silk fibroin. $J \mathrm{Mol}$ Biol 1966, 19:580-582.

30. Laemmli UK: Cleavage of structural proteins during the assembly of the head of bacteriophage T4. Nature 1970, 227:680-685.

31. Killander D, Dohlwitz A, Engstedt L, Franzen S, Gahrton G, Gullbring B, Holm G, Holmgren A, Hoglund S, Killander A, et al: Hypersensitive reactions and antibody formation during L-asparaginase treatment of children and adults with acute leukemia. Cancer 1976, 37:220-228.

32. Wilson D, Valluzzi R, Kaplan D: Conformational transitions in model silk peptides. Biophys J 2000, 78:2690-2701.

33. Zhang K, Fan L, Yan Z, Yu Q, Mo X: Electrospun Biomimic Nanofibrous Scaffolds of Silk Fibroin/Hyaluronic Acid for Tissue Engineering. J Biomater Sci Polym Ed 2011, 22:1069-1082.

34. Teramoto H, Miyazawa M: Molecular orientation behavior of silk sericin film as revealed by ATR infrared spectroscopy. Biomacromolecules 2005, 6:2049-2057.

35. Huang J, Wong C, George A, Kaplan DL: The effect of genetically engineered spider silk-dentin matrix protein 1 chimeric protein on hydroxyapatite nucleation. Biomaterials 2007, 28:2358-2367.

36. Mandal BB, Kundu SC: Biospinning by silkworms: silk fiber matrices for tissue engineering applications. Acta Biomater 2010, 6:360-371.

doi:10.1186/1479-5876-10-117

Cite this article as: Zhang et al:: Preparation and characterization of silk fibroin as a biomaterial with potential for drug delivery. Journal of Translational Medicine 2012 10:117.

\section{Submit your next manuscript to BioMed Central and take full advantage of:}

- Convenient online submission

- Thorough peer review

- No space constraints or color figure charges

- Immediate publication on acceptance

- Inclusion in PubMed, CAS, Scopus and Google Scholar

- Research which is freely available for redistribution 